\title{
Rethinking National Identities in Divided Societies of Post-Ottoman Lands: Lessons from Lebanon and Cyprus
}

\author{
Gulay Umaner Duba \\ Visiting Researcher in Political Science at the University of Helsinki ${ }^{1}$ \\ Nur Köprülü \\ Department Head of Political Science at Near East University²
}

\begin{abstract}
The communal identities rooted in the millet system are still salient in post-Ottoman lands. Cyprus and Lebanon offer two cases where ethnic and sectarian identities are more prominent than national identities. In this respect both countries represent highly divided societies in post-Ottoman territories. This article discusses the failure of power-sharing systems in Cyprus and Lebanon, arguing that the lack of cultivation of a common national identity at the founding of these republics remains even today a central obstacle to implementing stable multinational/sectarian democratic systems. As a part of Greater Syria, today's Lebanon is a homeland to many ethnic and sectarian communities. Lebanese politics historically has been governed by a system of consociationalism, which prevents any one group from dominating the political system. This system of power sharing dates back to the 1943 National Pact, and as a result of the sectarian nature of this arrangement, religious communal identities have a stronger pull than a Lebanese national identity. These communal identities crystallized over the course of a 14-year civil war, and were exacerbated by the assassination of former Prime Minister Rafiq al-Hariri in 2005. In the case of Cyprus, the possibility of cultivating a shared national identity between Turkish Cypriots and Greek Cypriots has historically been suppressed by kin-state relations and colonial policies which have, in turn, resulted in inter-communal conflict. An understanding of this conflict and the nature of the nationalisms of each community helps explain how the 1960 Constitution of a bi-communal and consociational Republic of Cyprus hindered inter-communal relations - a precondition for the cultivation of a common national identity - and ultimately failed. From enosis to taksimto the April 2004 referendum on the UN'sAnnan Plan, the contentious interaction between external constraints and collective self-identification processes subsequently reinforced ethno-religious identifications. Through an examination of such processes, this article aims to identify and illuminate the shifting forces that shape deeply divided societies in general, and that have shaped Cyprus and Lebanon in particular. Understanding such forces may help break down barriers to the development of common national narratives.
\end{abstract}

Keywords: Lebanon, Cyprus, ethnic/sectarian identities, civil wars, nationalism, millet system, power-sharing system

\footnotetext{
1 She earned her Ph.D. in Politics and Government at the University of Kent in the UK. Her research interests include federalism, ethnic conflict, normative theory, secessionist movements and ethnic minorities. She has several articles and book chapters on federalism, the Cyprus problem and ethnic minorities.

${ }_{2}^{2}$ She earned her Ph.D. in International Relations at Middle East Technical University. She specializes in Middle East politics in general, and the Hashemite Kingdom of Jordan in particular. Köprülü has published papers on democratization movements and identity politics in the Middle East including Jordan and Lebanon.
} 


\section{Introduction}

The communal identities rooted in the millet system are still salient in post-Ottoman lands. Cyprus and Lebanon offer two cases where ethnic and sectarian identities are more prominent than national identities. In this respect both countries represent highly divided societies in post-Ottoman territories.

As a part of Greater Syria (Bilad al-Sham), today's Lebanon is a homeland to many ethnic and sectarian communities, Maronite, Sunni Muslim and Shia Muslim, Druze, Greek Catholic and Greek Orthodox, and Armenian communities being among them. Lebanese politics historically has been governed by a system of consociationalism, which prevents any one group from dominating the political system. This system of power sharing dates back to the 1943 National Pact, and as a result of the sectarian nature of this arrangement, religious communal identities continue to have a stronger pull than a Lebanese national identity. These communal identities crystallized over the course of a 14-year civil war, and were exacerbated by the assassination of former Prime Minister Rafiq al-Hariri in 2005, which led to a surge in sectarian cleavages.

In the case of Cyprus, ethnic nationalism among Turkish Cypriots and Greek Cypriots hinders the cultivation of a common national identity. This paper will trace the identity concept in Cyprus from its religious and class basis during the Ottoman period, through the transformations shaped by the British colonial administration, to its present ethnicized form. After outlining the context of the Ottoman millet system and the rise of inter-ethnic unrest and the further politicization of ethnic cleavages under the British, the analysis turns to the 1960 Constitution, which under girded a weakly structured republic from which emerged the insoluble question of Cyprus. This paper argues that the combination of kin-state relations and colonial policy have fomented ethnic rivalries that led to inter-communal conflict in the 1960 s and 70 s. An understanding of this conflict and the nature of the nationalisms of each community helps explain how the 1960 Constitution of a bi-communal and consociational Republic of Cyprus hindered inter-communal relations - a precondition for the cultivation of a common national identity - and ultimately failed.

This article discusses the failure of power-sharing systems in Cyprus and Lebanon, arguing that the lack of cultivation of a common national identity at the founding of these republics remains even today a central obstacle to implementing stable multinational/sectarian democratic systems. Through examining key historical and political processes, the article aims to identify and illuminate the shifting forces that shape deeply divided societies in general, and that have shaped in Cyprus and Lebanon in particular. Identifying the forces at work may be useful for understanding more generally how societies/communities/groups coexisting in hostile environments may work to overcome the obstacles they face in realizing potential commonalities.

\section{The Case of Lebanon}

"Every individual is a meeting ground for many different allegiances, and sometimes these loyalties conflict with one another and confront the person who harbors them with difficult choices". Amin Maalouf ${ }^{1}$

\section{From Mount Lebanon to Greater Lebanon}

Lebanon is one of the most plural societies of the Middle East region, encompassing Maronite, Sunni Muslim and Shia Muslim, Druze, Greek Catholic and Greek Orthodox, and Armenian communities (Yapp 1995: 104). The state and nation formation of Lebanon has its roots in its status as an autonomous province during Ottoman times. According to Eli Fawaz, the social composition of Lebanon makes its distinctive in the region with "a spectrum of different religious minorities ... and a reputation of safe haven for them" (Fawaz 2009: 25). For William Harris, "Lebanon's pluralist politics evolved to

${ }^{1}$ Amin Maalouf (2000), In the Name of Identity: Violence and the Need to Belong, New York: Arcade Publishing. 
accommodate the pre-existing social reality of popular identification with various Muslim and Christian sectarian communities, each with its own leaders and preoccupations" (Harris 2009: 3).

\section{The Legacy of the Millet System}

Representing the Middle East region in microcosm, Lebanon began to enjoy "a political form and had considerable special privileges" (Salabi 1965) during the $17^{\text {th }}$ century. Mount Lebanon under Ottoman rule was mostly exempted from the direct influence of the central authority as long as it fulfilled its tax obligations.

It is imperative to emphasize that the backbone of the social order in Ottoman lands was the millet system, wherein the population was delineated according to "their religious affiliations or confessional communities" (Fawaz 2009: 29), rather than along ethnic or linguistic lines. Thus, the millet system allowed non-Muslims to autonomously regulate their own social and religious practices, and also granted them certain privileges. It was within this context that the cultural identities of Lebanon's minority groups were able to flourish.

Sectarian cleavages deepened with the decline of the Ottoman Empire. It was in this context that - with the 1864 establishment of the Mutasarrifiyya (autonomous region) administrative council - Mount Lebanon lost its privileged status. The administrative council was an elected, multi-sectarian advisory board, epitomizing a proto-parliament (Yapp 1995). State formation in Lebanon can thus be traced back to these $19^{\text {th }}$-century regional developments.

\section{French Colonial Rule and Nation Formation in Lebanon}

As a part of Greater Syria, today's Lebanon was founded in 1920 through French mandatory rule under the supervision of the League of Nations. In Nazih Ayubi's words, "Mount Lebanon, a small geographic zone that was gradually extended to include all Maronite and Druze areas, was converted by France into a greater Lebanon in 1920, through the annexation of the (mainly Sunni and Shia) coastal towns, Jabal 'Amil and the Biqa' Valley according to a system of deliberate privilege for the Maronite Christians" (Ayubi 1995: 114). The first French High Commissioner in Lebanon, General Henri Gouraud, was the architect of the Maronite territorial demands during this period (Yapp 1995: 105). Gouraud established Maronite nationalism on several symbolic myths that emphasized the historical interaction of Mount Lebanon with the Mediterranean and linked Maronites to the Syrian Orthodox monk Maron and the Phoenicians (Kaufman 2004; Yapp 1995). The Maronite project of statehood thus had two aims: to stand on its own and to be for Christians (Yapp 1995: 105). Kaufman argues that the formation of Grand Liban (i.e. Greater Lebanon) was rooted in "the cooperation between French colonial circles and Christian Lebanese nationalists whose interests converged in the post-First World War years" (2004: 2). Similarly, in Nazih Ayubi's words, "Mount Lebanon, a small geographic zone that was gradually extended to include all Maronite and Druze areas, was converted by France into a greater Lebanon in 1920, through the annexation of the (mainly Sunni and Shia) coastal towns, Jabal 'Amil and the Biqa' Valley according to a system of deliberate privilege for the Maronite Christians" (Ayubi 1995: 114).

In fact, it was not until 1920 that Lebanon became detached from Greater Syria by the French Mandate and established as a separate entity for the first time in its history. Given the absence of a majority religious, sectarian or ethnic group, French rule was founded on a formula of confessional power sharing, which was then incorporated into the very underpinnings of the Lebanese state in 1926. The power-sharing formula of the Lebanese political system was based on the demographics of the national census conducted in 1932, according to which Maronites (Arab Catholics) comprised 29\% of the population, Sunnis 23\% and Shiites 20\% (Yapp 1995). The rest of the population was divided among the Druze, Greek Catholic, Greek Orthodox and Armenian communities. The formula to rule mandate was allocated in accordance with the proportion of each sectarian group. In this sui generis power-sharing model, the president of the republic is elected from among the Maronites, the prime minister from the Sunnis, and the speaker of the parliament from the Shias. Thus, confessionalism granted reassurances that no one group could dominate the political system. This system of proportional representation in government was integrated into the 1943 National Pact (Lebanon Political Profile 2006: 4). As Michael Hudson states, 
"... the 1943 National Pact brought Muslims into the system as Lebanon embarked on independence. Although MuslimChristian tensions were never erased, they were managed fairly successfully over the period from 1943 to 1975 . Under President Bishara al-Khoury a "grand coalition" of sectarian and feudal-business "notables" ran the country in a manner that roughly fits the consociational model" (Hudson 1997: 107-108).

Anthony Smith defines a 'nation' as "a named human population sharing an historic territory, common myths and historical memories, a mass, public culture, a common economy and common legal rights and duties for all members" (1991: 14). ${ }^{1}$ Benedict Anderson argues in his masterpiece Imagined Communities that tangible communities or nations are in fact imagined and rely upon the manipulation of history and encouragement of nationalist sentiments to ensure a community or nation's survival. As he puts it, "It is the magic of nationalism to turn chance into destiny" (Anderson 1983: 11-12).

Lebanon, being inextricably linked to these confessional categories since the early years of the mandate rule, has lacked an 'overarching' national identity or inclusive 'Lebanonism', which would be an instrumental tool of cohesion in times of conflict, instability or war. Stewart suggests that Lebanon has a common identity and shared goals, but that they are not encouraged, and that while the country's diverse character invites tolerance and coexistence on the one hand, it has also made it vulnerable to external influence on the other (Stewart 2012). Within this socio-political context, a Lebanese individual acquires his or her social identity through familial bonds and religious affiliation rather than the Lebanese nation:

"The trust required to build secure identities has rarely been provided by the state. Instead, it has consistently derived from the family, the tribe, the sect. These ties do not necessarily come at the expense of 'nation'; instead the complex nature of identity allows for allegiances along multiple lines" (Stewart 2012: 178).

In the case of Lebanon, it is apparent that the micro-societies system helped people survive, particularly during and after the civil war. On the other hand, with respect to nation-building Stewart suggests that; "problems arise when various groups lay claim to a country's past, present and future" (Stewart 2012). Political parties and coalitions are also formed on the basis of confessional, personal and kinship ties. ${ }^{2}$ In the Lebanese sectarian system, then, "closed communal identities are not only the basis for identity and belonging, but also for access to education and services" (Lebanon: The Persistence of Sectarian Conflict 2013: 4).

\section{The Civil War: A test for Lebanese Identity}

Lebanon's mix of minorities has caused it to be viewed as a microcosm of the complex religious and political divisions of the Middle East region as a whole. With roots in the Phoenician past and strong ties with the West, Lebanese nationalism has seen "the incorporation of larger Muslim populations into Lebanon as irreconcilable with its ideology ... setting the Lebanese people apart from any concept of an 'Arab nation' (Stewart 2012: 162). The increase in the Muslim population

\footnotetext{
1 Later on Smith formulates an 'ideal-type' definition of the nation as "a named community possessing an historic territory, shared myths and memories, a common public culture and common laws and customs" (Montserrat Guibernau 2004: 127).

2 The Movement of the Future (Tayyar al-Mustaqbal), which is under the leadership of Saad Hariri, the son of former Prime Minister Rafik Hariri (who was assassinated in 2005) has been supported by Sunni Muslims in the country and forms the main faction in the March 14 Alliance. Similarly, the Lebanese Forces supported by Maronites - Arab Catholics - were led by Samir Geagea, "who was arrested in 1994 on charges of attempting to undermine government authority by 'maintaining a militia in the guise of a political party,' of instigating acts of violence, and of committing assassinations during the Lebanese Civil War. As a part of the March 14 Alliance, this group then became part of the March 14 Coalition. The Kataeb Party - which is also know as Phalangists - has its main support base from the Maronite community. This group advocates an anti-Iranian and anti-Syrian regime stand, which became apparent after the assassination of former Prime Minister Rafiq al-Hariri in 2005. For instance, Pierre Gemayel, the Maronite leader of the Phalange militia stated that, "Lebanon is a mission", and the Maronite community often conducted itself in such a manner. Similarly, under the leadership of Nabih Berri, the Amal Movement represents one of the two main Shi'i parties in the country. The Movement has pro-Syrian stand and advocates Syrian military presence in Lebanon. The Amal Movement is one of the allies of the March 8 Coalition in the 2009 parliamentary elections. Finally, Hezbollah represents a Muslim Shi'i political party in Lebanon. Allied with the Syrian Bath Party and Iran, today it forms the biggest faction in the March 8 Coalition (See http://carnegie-mec.org/2015/04/17/lebanon-situation-report-pub-59832, Carnegie Middle East Center).
} 
with the creation of Greater Lebanon, and later on with the influx of Palestinians in the aftermath of Black September, have threatened the dominance of Maronite Christians and Lebanon as a homeland for them. Meanwhile, the political structure of Grand Liban was viewed by its Muslim populations as safeguarding their representation in the political system. Lebanon continued to accommodate its complex religious confessional makeup through its power-sharing formula in the postindependence years, but various internal and regional dynamics strained this delicate system of governance and triggered sectarian fragmentation.

Foremost among these dynamics during the 1970s was the call from the Shiite community - which was concentrated in economically deprived southern Lebanon - for a political reconfiguration that would grant it 'real' political and economic power. These demands were based on the argument that the 1932 census was no longer representative of the demographic proportions of the country. ${ }^{1}$ The aftermath of the Black September episode in 1971 also brought an influx of Palestinian resistance members into southern Lebanon. These developments created a regional dynamic vis-à-vis the Palestinian national movement, which within Lebanon constituted a matter of concern for the central government over the legal status of Palestinians relative to its delicate formula of confessional governance. In the Arab Middle East, the Hashemite Kingdom of Jordan represents the only case wherein Palestinians have acquired full rights to citizenship. As Imad Salamey and Rhys Payne stated,

"the 'quotated' political power-sharing arrangement has historically favoured Christians over Muslims, as reflected in the proportional allocation of public offices in favour of Christians. Muslim resentment has been a major reason for domestic turmoil and civil wars since the 1940s. Beside the demographic factor, Lebanon's geostrategic position, in the midst of major regional and international battling powers, allowed the confessions to establish alliances with foreign countries and draw substantial support from them" (Salamey and Payne 2008: 452).

Having felt external pressure with the outbreak of and throughout the civil war, Lebanon, as a small country, was caught between the demands and rivalries of insiders and outsiders. Syrian and Israeli interventions into the Lebanese Civil War in 1976, 1978 and 1982 also proved that the conflict extended beyond its own borders. Syrian intervention in Lebanese internal affairs began in 1976 when Syrian President Hafiz al-Assad sent 30,000 troops to Lebanon under the label of the Arab Deterrence Force. The Taif Accords that finally put an end to the 14-year civil war has granted Syria a special role in Lebanese politics ever since. The war highlighted the fragility of the Lebanese common identity; the power-sharing mechanism ultimately failed, devastating the nation- and state-building project as parochial and sectarian identities and loyalties crystallized.

\section{The Interplay between Sectarianism, the War in Syria and Lebanese identity}

The onset of the Arab Spring and the Syrian Crisis had a prompt impact on Lebanese political life, exacerbating the internal sectarian cleavages precipitated by the assassination of Sunni-origin former Prime Minister Rafiq al-Hariri in a bomb attack in central Beirut on 14 February 2005. The assassination of Hariri had triggered increasing polarization between Lebanon's Sunni and Shia populations, ushering in its most unstable period since the end of the civil war. On the one hand the March 8 Alliance, under the leadership of Hezbollah, responded to these regional developments with a pro-Syrian regime stance, while on the other the March 14 Alliance, under the leadership of Sunni politician Saad al-Hariri (son of Rafıq al-Hariri), took a pro-Syrian opposition and anti-Iranian stance.

These policy stances towards Syria were informed by domestic developments. In 2006, within the framework of national dialogue sessions, the Baadba Declaration had been issued, marking a rejuvenation of the historic compromise between the two camps in Lebanon (Al-Monitor 2013). The declaration was committed to Lebanon's disassociation from Syria and

\footnotetext{
1 Due to the delicate power-sharing system on the basis of population size in the country, no census has been taken since 1932 . According to Central Intelligence Agency (CIA) - as of 2005 - "Lebanese population is approximately 3.8 million, of which Muslim groups comprise $39 \%$ with another $1.3 \%$ of assorted religious affiliations" (Lebanon Political Profile 2006: 5).
} 
featured the stipulation that Lebanon would not be "a passageway for the smuggling of weapons and personnel into Syria" (Middle East Report). Since then, two important events have reignited the internal cleavages between the two political coalitions. The first was the 2006 assassination of Wissam Hassan, the head of the Information Branch of Lebanon's Internal Security Forces, and the second was the arrest of former Lebanese Information Minister Michel Samha, a supporter of the Syrian regime, in August 2012. Thus, the spirit of the Baadba Declaration was lost, and Lebanon entered the postArab uprisings epoch with the legacy of a proxy war.

The divergent interests of the March 14 and March 8 camps vis-à-vis the crisis with Syria have hindered efforts by Lebanon's leaders to reach the necessary compromises to accommodate its political system since Rafiq Hariri's 2005 assassination. Saad Hariri's Future Current Party has brought Hezbollah's military arsenal onto the agenda, with one party official claiming that "Hezbollah has an arsenal that even the Lebanese Armed Forces don't" (ICG 2012: 21). In response, Hezbollah has tried to justify its military arsenal by arguing that it needs to deter external forces such as Israel from making Lebanon "a staging ground to destabilize Syria" (ICG 2012: 16). As summarized by the International Crisis Group (ICG),

"Lebanon's factions clearly are aware of the stakes. Each wagers on success by one Syrian side or the other, waiting to translate the ensuing regional balance of power into a domestic one. Hizbollah hardly can contemplate a future with a fundamentally different Syrian regime, has tied its fate ever more tightly to its ally's, and will not remain idle should Assad be in real jeopardy. Conversely, the Sunni-dominated Future Current and its partners see no alternative to the regime's demise, however long it will take and no matter the costs. They view the uprising as doubly strategic: a golden opportunity to seek revenge against an antagonistic regime as well as a chance to challenge Hizbollah's domestic hegemony. It is hard to see Lebanon's fragile equilibrium surviving such a winner-take-all mentality" (International Crisis Group 2012: 16)

Today, Hezbollah maintains its pro-Assad stance, and declared a second victory in Syria after the outbreak of the uprisings in the city of Daraa. Hezbollah leader Nasrallah also warned that, if Syria falls, Jerusalem will fall as well (Taşdemir 2013). Hezbollah's support of Bath rule in Syria cannot be reduced to sectarianism or their Shiite connection; it is also closely tied to the fact that, if Bashar Assad is deposed, his regime will be replaced by a Sunni-dominated regime, which would restrict Hezbollah's capacity to resist Israel around the region, as well as its position within Lebanon. This support also corresponds with Iran's participation in this 'proxy war' over Syria. All of these conflicting regional alliances and policies point unfavourably toward the possibility that an overarching Lebanese identity can be cultivated which would encourage coexistence.

\section{The Case of Cyprus}

This section deals with the development of ethnic nationalisms among Turkish and Greek Cypriots in Cyprus, which hinders the cultivation of a common national identity. The analysis will trace the transformation of the identity concept in Cyprus from it religious and class basis during the Ottoman period, through the transformations shaped by the British colonial administration, to its present ethnicized form. Firstly, the Ottoman millet system will be explained for the case of Cyprus. Secondly, the reasons for the intensification of inter-ethnic conflict and the further politicization of ethnic cleavages under the British colonial administration will be examined. Thirdly, the 1960 Constitution will be analysed in order to reveal the weak structure of the republic, which resulted in the insoluble question of Cyprus. This paper argues that kin-state relations, in combination with British colonial policy, fomented ethnic rivalries that resulted in inter-communal conflict in the 1960s and 70s. An understanding of this conflict and the nature of the nationalisms of each community helps explain how the 1960 Constitution of a bi-communal and consociational Republic of Cyprus hindered inter-communal relations - a precondition for the formation of a unified national identity - and ultimately failed.

\section{Identity Formation under Ottoman Rule}

Ethnic divisions in Cyprus originated as the product of an institutional design that dates back to the Ottoman millet system, which organized communities along religious lines. Political regimes on the island to this day preserve this principle when 
delineating majority and minority populations. As a result, Cypriot political systems have been resistant to societal demands for recognition of greater diversity within and among various societal groups, for example the effort to increase interaction between Muslims and non-Muslims (Alptekin 2010). The Ottoman legacy had been the peaceful coexistence of semiautonomous communities, including limited interaction across communities within the same villages, rather than a common life based on shared social, judicial and moral grounds or hostility with potential violent conflicts. Therefore, the ability of Turkish and Greek Cypriots to cultivate a shared cultural heritage from which a unified national narrative could emerge had been suppressed historically.

Under Ottoman rule the two main communities tended to identify themselves as either Orthodox or Muslim, and the political system encouraged the tendency towards separation. The millet system institutionalized each religious group as a distinct cemaat/community that elected its own judicial and administrative officials. "This exclusive political socialization over a long period of time contributed to the crystallization of separate ethnic identities and aspirations" (Yilmaz 2008: 429). The propensity of both communities to identify themselves with the larger Greek and Turkish nations in the post-Ottoman period reinforced such separation. The historically antagonistic relations between Greece and Turkey had a great impact on the two Cypriot communities' relations with each other and hindered the cultivation of a common Cypriot identity.

\section{Identity Formation under British Rule}

Under British rule, no significant steps were taken to generate harmony, asBritain never identified a single Cypriot tradition, but rather interpreted the Ottoman categories of 'Orthodox' and 'Muslim' as 'Greeks' and 'Turks'. The millet system was thus retained in a different form under British rule. "Village administrative councils were segregated and handled community affairs separately, with specially formed Joint Councils for the adjudication of matters common to both groups" (Calotychos 1998: 5-6). The new administrative policies necessitated the politicization of group cleavages, and eventually identification of the communities in terms of ethnicity. This ethnicizing - as opposed to territorializing - approach to political organization institutionalized difference rather than commonality, and segregation rather than interaction. In addition, as part of the British administration's advocacy of public education, it imported school books and teachers from Turkey and Greece and established separate schools; it also imported press from the two young 'mainland' republics, circulating aggressively nationalist publications which formulated separatenational consciousnesses among Cyprus' 'Greeks' and 'Turks' (Papadakis 2005: 143). In other words, Greek Cypriot nationalism and Turkish Cypriot nationalism were imported rather than being generated locally (An 2015: 25).

The British administration's ignorance of Greek Cypriots' demands forenosis (the ideal of unification with mainland Greece) reinforced their Hellenic nationalism. Intensifying anti-colonial sentiment among Greek Cypriots, as manifested in the violent acts of EOKA (National Organization of Freedom Fighters), pushed the Turkish Cypriot population closer to the British administration, as these were demands not for independence, but for the transfer of sovereignty from Great Britain to Greece. The millet system had already divided the two societies of the island, but with enosis this escalated to antagonism under British rule. Nationalism among Turkish Cypriots developed as a defence contra-nationalism against enosis, as the population sensed the possibility that demands for enosis would lead to Greek Cypriot domination. In response, they demanded taksim(partition of the island between Turkey and Greece); violent Turkish Cypriot organizations like the TMT (Turkish Defense Organization) also emerged. The psychological distance between the two communities thus further widened in the 1950s. Once intercommunal fighting started, the old hatreds and mistrust that had characterized GrecoTurkish relations since the fall of Constantinople were renewed with increasing intensity (Yilmaz 2008).

\section{The Republic of Cyprus and Identity Policy}

During the British administration, Turkish Cypriot and Greek Cypriot communities developed different national ambitions, and interference by Greece and Turkey in Cyprus reinforced these ambitions. This interference and the constitution of the 1960 republic, which was also characterized by communal dualism, further widened the gap between communities. 
The Republic of Cyprus was established in 1960 under three guarantor states: Turkey, Greece and the UK. Greek and Turkish Cypriots alike were disappointed not to have achieved union with their purported national motherlands. "Drafted by the Greek and Turkish governments, it [the 1960 constitution] contained in it provisions for segregation at all levels between the Greek and Turkish communities, thus making the constitution virtually unworkable" (Zarocostas 1980: 108). Although the constitution set up a power-sharing system, it did not emphasize a common Cypriot nation or identity; instead it intensified Greekness and Turkishness. According to the constitution, the Greek community comprised "all citizens of the Republic who are of Greek origin and whose mother tongue is Greek or who share the Greek cultural traditions or who are members of the Greek-Orthodox Church", whereas the Turkish community comprised "all citizens of the Republic who are of Turkish origin and whose mother tongue is Turkish or who share the Turkish cultural traditions or who are Moslems".

In other words, the constitution established two sets of parallel political institutions to separately govern each community. Separate representation was preserved, and the representatives of each community were given such powers as to make collective decisions. (Hitchens 1997: 50-55). The two Communal Chambers granted both executive and legislative powers to each community separately within the House of Representatives and Ministries. The separation of political power by ethnicity forced members of the public to identify with either a Greek or Turkish identity, thus hindering national unity. Although the 1960 Republic had its own flag of neutral design and colour, according its constitution "the Communal authorities and institutions shall have the right to fly on holidays together with the flag of the Republic either the Greek or the Turkish flag at the same time"."The Greek and the Turkish Communities shall have the right to celebrate respectively the Greek and the Turkish national holidays". ${ }^{1}$ Moreover, each community was given the right to receive government subsidies from Greece or Turkey for the institutions of education, culture, athletics and charity. Also, "where either the Greek or the Turkish [Cypriot] Community considers that it has not the necessary number of schoolmasters, professors or clergymen for the functioning of its institutions, such Community shall have the right to obtain and employ such personnel to the extent strictly necessary to meet its needs as the Greek or the Turkish Government respectively may provide". ${ }^{2} \mathrm{As}$ observed, both sides relied and still rely on the dualistic identity structure that has its roots in the millet system. Moreover, as Hadjipavlou also states, "even after independence, each ethnic group showed more loyalty to their own 'motherland' than to the state of Cyprus and its state symbols"(2007: 357).

The concept of separation by ethnicity in the 1960 Constitution contained provisions for joint activities between the two communities. This resulted in the crystallization of two national identities - Greek and Turkish - and ultimately the failure of the power-sharing model of the Republic of Cyprus in 1963.President Makarios proposed changes to 13 chapters of the constitution, including the removal of consensual elements which guaranteed Turkish Cypriots a share of the power. According to Turkish Cypriots, this would have transformed the republic into a pan-Hellenic nationalist Cypriot state.

However, in reaction to political developments in Greece (a military junta came to power in 1967), Makarios abandoned theenosis program and requested an independent Unitarian Cyprus. The two communities negotiated until 1974 but made no headway. The de facto division of the island since 1974 and the Turkish Cypriot leadership's unilateral declaration of independence (as the Turkish Republic of Northern Cyprus) in 1983 have further complicated hopes for a resolution to the ethno-national conflict in Cyprus.

As Joseph S. Joseph states,

"Despite four centuries of coexistence, the two communities remained separate, distinct, and self-contained ethnic groups divided along linguistic, religious, and cultural lines. Political division and attachment of the two groups to their motherlands

\footnotetext{
1 "The Constitution of the Republic of Cyprus", Article

2 http://www.presidency.gov.cy/presidency/presidency.nsf/all/1003AEDD83EED9C7C225756F0023C6AD/\$file/CY_Constitution.pdf

2 Constitution of the Republic of Cyprus, Available at: http://www.kypros.org/Constitution/English/
} 
then reinforced the ethnicity. The lack of cross-cutting ethnic, social or political ties prevented the development of a common Cypriot political culture and overarching loyalties among the two groups"(1985: 33).

The 1960 establishment of the Republic of Cyprus had institutionalized this division (Joseph 1985). One implication of its constitution was that the government and the legislature was composed of ethnic Greek and Turkish members who represented the interests of, and were primarily responsible to, their own communities. As Zenon Stavrinides states, "Although they were all, in a sense, Cypriot leaders the very constitutional arrangements under which they reached public office were such that their Greekness or Turkishness was of fundamental importance"(1999: 6). As Burgess also points out, "In retrospect, [the 1960 Constitution] had the unfortunate consequence of emphasising, to the point of exaggeration, the 'separateness' of the two communities"(2007: 130). This bi-communal system had relied on an extremely delicate balance between centrifugal and centripetal forces influencing the polity, but with the emphasis on institutional separation, parallelism and reciprocal veto, the constitution had instead created a polity with too few powers, functions and overlapping relationships that was not equipped to provide its people withan overarching sense of national state unity (Burgess 2007).

\section{Developments after the Failure of the Bi-communal Republic of Cyprus}

Several developments during the period before 1974 need to be analysed in order to understand the impact of the interventions by Greece and Turkey into the internal affairs of Cyprus; mass public support of enosis and taksim; political conflict over the power-sharing system of the 1960 constitution and the emergence among Turkish Cypriot elites of a concept of the nation based on biological principles. ${ }^{1}$ These developments had reframed the concepts of sovereignty, collective identity, power-sharing and territoriality as a source of conflict, ultimately leading to the disintegration of the 1960 Republic (Vural and Peristianis 2008: 41-43).

As a result of inter-communal violence in 1963, Cyprus was divided into two ethnically distinct areas. And since the 1974 war and partition of the island the two communities have grown increasingly apart, affecting identity perception. In the case of Turkish Cypriot identity, thedivision of the island into two ethnically homogenous zones resulted in the formation of a strong link between identity and territoriality. Indeed, despite official Turkish policy emphasizing the unity and uniformity of the Turkish nation as a whole, Turkish Cypriots' emphasis on the difference between themselves and mainland Turks in recent years has become progressively stronger.This shift in identity perception has occurred in reaction to the open intervention of Turkey into TRNC affairs, fear of the arrival of Turkish immigrants from Turkey, the rapid emigration of Turkish Cypriots abroad, military influence, and as a result of its economic and political isolation. Turkish Cypriots have begun to link their national identity to Cyprus as a whole, as reflected in a referendum in 2004 when $64.9 \%$ of Turkish Cypriots voted in favour of unification (Riegl 2008).

It can be argued that identity policy after 1974 has led to dynamic developments in the formation of a common national identity (Cypriotness). While Turkish Cypriots have begun to identify themselves more strongly with Cyprus, Greek Cypriots have also refused the enosis program for the most part. Hardliners in both communities have been replaced by constructive soft-line elites. However, despite bi-communal activities and the efforts of a bi-communal civil society, the two ethnic communities retain strong political and cultural ties with Greece and Turkey that have slowed rapprochement. From the

1 To legitimize the Cyprus division, an official identity policy was accepted in Northern Cyprus rejecting the existence of the Turkish Cypriots and emphasizing the existence only of the Turks who live in Cyprus. The Turkish Cypriot leader Rauf Denktash describes this as, "I am a child of Anatolia. I am a Turk from all my heart with my roots in Central Asia. I am a Turk by culture, language and I share our joint history. The terms like a joint state, Cypriot culture, Cypriot Greeks and Cypriot Turks are nothing but empty words" (Kizilyurek and Kizilyurek, 2004: 48). 
struggle for enosis and taksimto the April 2004 referendum politics, the interaction between external constraints and collective self-identification processes has propagated a variety of identity concepts, including ' 'Motherland nationalism','Cypriotism','Greek Cypriotism' and 'Turkish Cypriotism'. These identity shifts will heavily influence the resolution of the Cyprus problem.

Recent UN proposals and ongoing negotiations towards the reunification of the island continue to lack the elements necessary to cultivate a common national sentiment or Cypriot identity. Article 3 of the latest UN Plan, called the Annan Plan, explicitly specifies that the exercise of political rights is tied to ethnic identity: "Other than in elections of senators, which shall be elected by Greek Cypriots and Turkish Cypriots separately, political rights at the federal level shall be exercised based on internal constituent state citizenship status. Political rights at the constituent state and local level shall be exercised at the place of permanent residency." In other words, no citizen can undertake a political activity as a Cypriot, but must identify himself or herself as Turkish or Greek. No constitutional proposal put forward has seriously envisaged an electoral system for the federal executive that favours moderates and encourages cooperation (i.e. a cross-voting system which could include modest centripetalists). An appropriate electoral system (i.e. countrywide rather than ethnicity based) that has the structural capacity to bind the federation together while simultaneously representing and accommodating the social diversities expressed by sub-national parties in the federal polity, needs to be explored for successful reunification of the island.

\section{A Common National Identity: Cypriotness/Cypriotism}

National identity is the primary form of identity that generates a sense of belonging and unity, offering people authenticity, historical continuity and rootedness in a common territory (Dieckhoff and Gutierrez 2001). It relies on the oppositional images of 'us' and the 'other' to achieve unity among members of a particular 'us-group' and affirm its distinction from a 'they-group' (Billig 1995). The concept of the nation can accommodate multiple subordinated identities and binds people together despite differences (Calhoun 1997). Since nations are discursively constructed,the definition of who is included within and excluded from the category of 'the nation' can evolve alongside the ever-changing political context of its production (Reicher \& Hopkins,2001). Itsconstructednessmust then be naturalized and embedded within the routines of everyday life (Billig 1995; Edensor 2002; Ożkırımlı 2000).

Cypriotness has emerged as a political ideology in response to the shortcomings of ethno-religious nationalisms. For example, in the context of the establishment and later dissolution of the 1960 Republic, for Greek Cypriot nationalists, a concept like Cypriotness would have threatened the unity of Hellenism and the Greek character of Cyprus, while Turkish Cypriot nationalists feared the idea of Cypriotness would not meaningfully include them. As Vural and Rüstemli argue, 'Cypriotness' has been the territorial-civic component of collective identity, which was used by members of the GreekCypriot and Turkish-Cypriot communities to separate their identities from mainland Greece and Turkey respectively (2006: 332). However, civic nationalism has not been strong enough to challenge the hegemony of nationalist ideologies that have emphasised Greek or Turkish ethnicity and the desire of many Turkish and Greek Cypriots to see themselves as parts of greater nations.

The idea of Cypriotism has its roots in the political left (Mavratsas 1996: 92). Cypriotism within Greek Cypriot society began with abi-communal character and a strong antagonism toward Greek nationalism (Hamit 2009: 52). Similarly, from the early 1980s through the early 2000s, Cypriotism among Turkish Cypriots had a bi-communal character and a strong antagonism toward Turkish nationalism and the immigrant population from Turkey, who came to be regarded as a threat to Turkish Cypriot identity. Recent evidence on intergroup relations between Turkish Cypriots and Turks from mainland Turkey indicates a clearer separation between the two communities (Cakal 2012). However, for the Turkish Cypriot Community, the bi-communal character of Cypriotismhas become less important as a result of the rejection of the Annan Plan by the Greek Cypriot community in the 2004 referendum. 
Both communities have felt a groundswell of 'Cypriot identity' or 'Cypriotness' based on 'historical, cultural and social dimensions' of their experiences (Faustmann 2003). The dominant concept of Greek Cypriot nationalism has often been challenged by ideas of national consciousness (Mavratsas 1997: 15). Consequently, despite its bi-communal nature, Cypriotism as an ideology (rather than as a national identity) has had different meanings and has evolved differently in each community. What is common to Cypriotism among both Greek and Turkish Cypriots is that it was a response to "disjunction to the Greek and Turkish nationalisms" (Hamit 2009: 51). Cypriotism can be regarded as a discursive representation of a nation or imagined community constructed as an inclusive and unifying collective identity for Cyprus (Vural \& Rüstemli 2006: 332). However, in reality the contradictory and exclusionary character of nationalist ideologies remains an obstacle to resolving the Cyprus problem.

According to the Cyprus 2015 poll, large majorities from both communities consider themselves to have either Greek or Turkish cultural roots. However, whereas large majorities of Turkish Cypriots consider Turkey to be their 'motherland', a significant number of Greek Cypriots do not consider Greece to be their 'motherland'.

Table 1: National and Cultural Identity (Greek Cypriots)

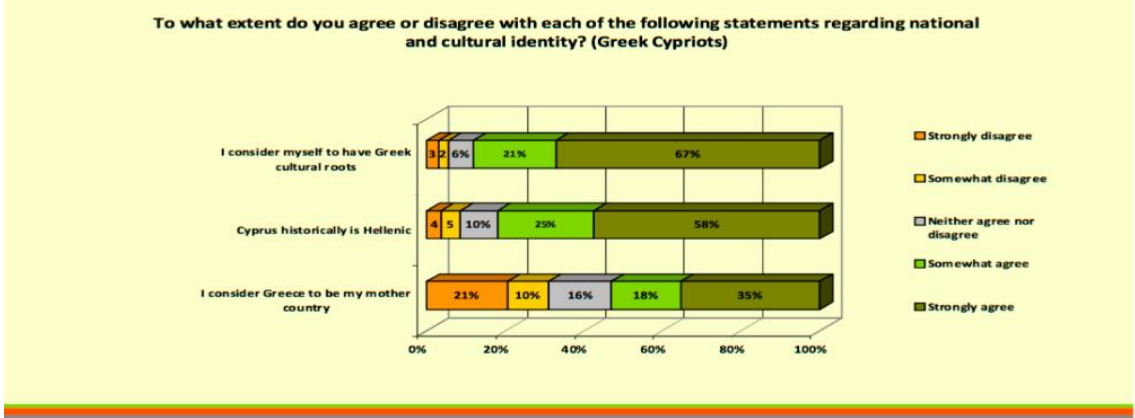

National and Cultural Identity (Greek Cypriots)

Greek Cypriots still tend to identify strongly with their Greek cultural roots, but many of them have now abandoned the notion of "Greece as mother country".

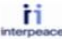

Table 2: National and Cultural Identity (Turkish Cypriots)

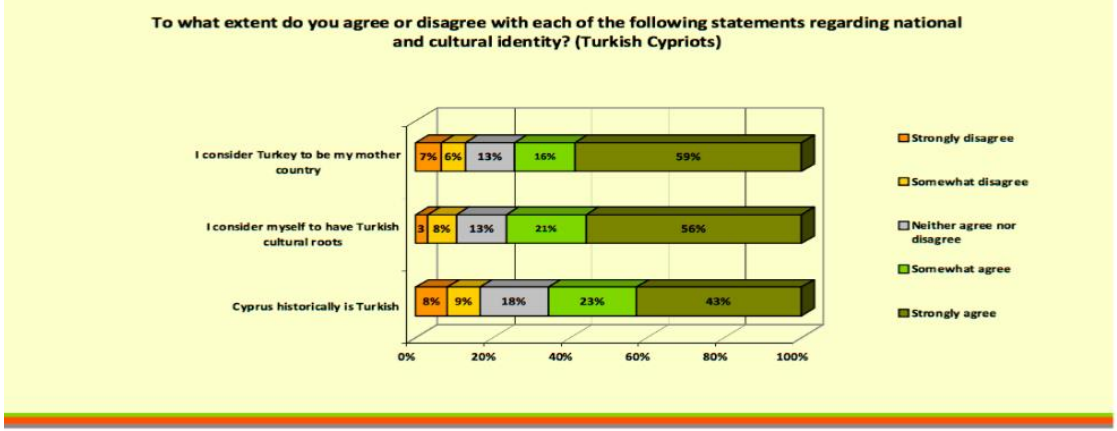

National and Cultural Identity (Turkish Cypriots)

Turkish Cypriots still remain loyal to the notion of "Turkey as motherland", at least to the extent that a majority of them acknowledges having Turkish cultural roots.

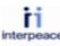


Table 3: Self-identification

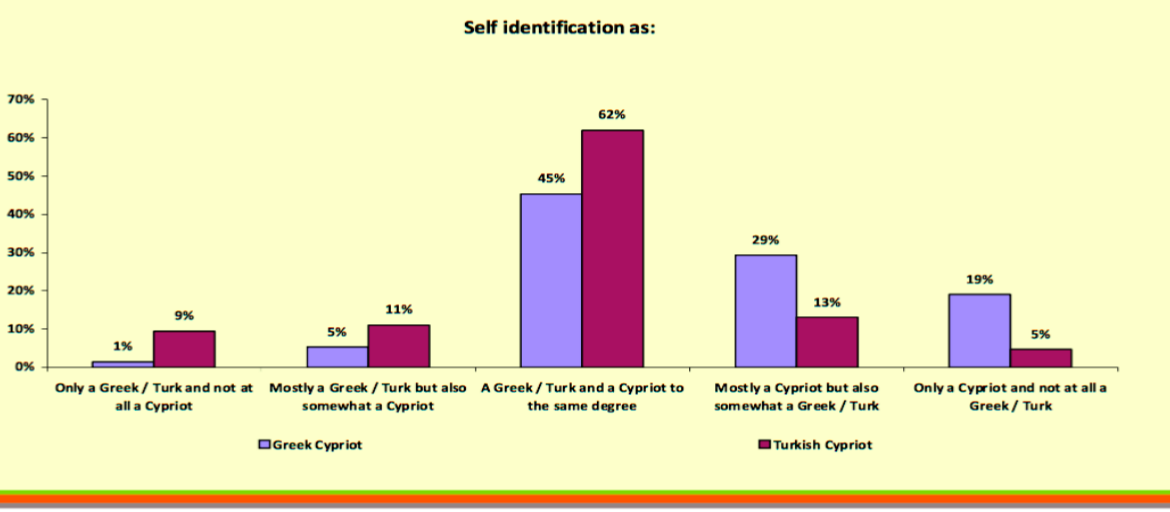

\section{Managing contested identities}

Greek Cypriots are equally divided between thase who consider themselves more Cypriot than Greek and those who consider themselves Greek and Cypriot to the same degree while few consider themselves to be more Greek than Cypriot. Turkish Cypriots present a more uniform picture, with a clear majority considering themselves to be Cypriot and Turkish to the same degree, and about equal minorities considering themselves, on the one hand, to be more Cypriot than Turkish, and on the other hand, more Turkish than Cypriot.

According to Table 3, the subgroup identity of both communities is high, as opposed to more exclusive ethnic or national identities. Significantly, few Greek Cypriots consider themselves Greek only. A significant number of Greek Cypriots claim to be Cypriot only. By contrast, Turkish Cypriots mainly identified themselves as Turkish Cypriots, and relatively few considered themselves to be Cypriot. Among both communities, only small percentage identifies themselves exclusively with the 'motherland'identity. Equal minorities of Turkish Cypriots consider themselves, on the one hand, to be more Cypriot than Turkish, and on the other hand, more Turkish than Cypriot.

However, in order to achieve a viable reunited federal Cyprus,an inclusive form of Cypriot identity/Cypriotness must be cultivated. Reduced commitment to Cypriot identity and stronger attachment to 'motherlands' - mainly due to exclusionary identities and a sense of threat from the other community - have resulted in a deterioration in relations between the two communities. It remains hard to change these views, as they have been reinforced by collective memory, master narratives, rituals and 'national' celebrations (see Psaltis \& Cakal, 2016), and the process of reunifying Cyprus has reached a stalemate.

\section{Conclusion}

The legacy of differentiation in Cyprus among communities under Ottoman rule and inter-ethnic tension in the late-Ottoman period was retained through strong ethnic identifications and polarization under the British colonial administration. This legacy was felt in the 1960 Constitution, and to some extent in the UN-led proposals so far. Additionally, geographical division and low levels of contact between the two communities indicate that Cypriot identity is still not embraced by both communities. The micro-society affiliations or sub-state identities have always been stronger than that of national identity in the case of Cyprus. Inter-communal conflicts led to the collapse of the common republic in 1963 and triggered the rise of ethno-nationalism on both sides.

In the case of Lebanon, although its ethno-religious pluralism made it exceptional as a place of tolerance and coexistence during the Ottoman period, the same diversity and pluralism led the country to open itself to external influence. The competing influence of these various regional actors on the Lebanese political landscape has brought conflicting outlooks regarding the future of the country. During the civil war, the confrontation was between Muslims and Christians, however 
in the post-Hariri assassination era, the social polarization has shifted. The new March 8 Alliance comprising mainly Shias represents one faction, and the March 14 Alliance under the leadership of Maronites and Sunnis is on the other.

In this respect, Lebanon and Cyprus have illustrated that building common national identities in the divided societies of the post-Ottoman lands requires in-depth analysis. The case of Cyprus has suggested that the ethnic nationalisms (Turkish and Greek Cypriot nationalism) and affiliations with the imagined motherlands of each community is still salient, and the lack or weakness of a territorial identity is one of the main obstacles to building a unified future for the island. In the case of Lebanon religious affiliations and identities like Maronite, Sunni, Shia or Druze also remain more influential than Lebanese identity. The Maronites on one hand historically have felt a sense of ownership over Lebanon based on reference to its Phoenician heritage; on the other hand, the Shias perceive their future with Syria based on historical and sectarian ties. In brief, both cases have shown that the legacy of millet system - which socially organized populations in the Ottoman territories by religious community (cemaat, communal identity) - is still endemic in the region.

\section{References}

[1] Al-Monitor. 2013. 'Lebanese Independence from 1943 Pact to Baabda Declaration'. http://www.almonitor.com/pulse/originals/2013/11/lebanon-independence-baabda-declaration-syria.html

[2] Alptekin, Huseyin. 2010. 'Millet System is Alive: Path-Dependency in Turkish and Cypriot Minority Incorporation Patterns', APSA 2010 Annual Meeting Paper. Available at SSRN:

https://ssrn.com/abstract=1644664

[3] An, Ahmet. 2015. 'Cypriotism and the Path to Reunification'. James Ker-Lindsay (ed.), Resolving Cyprus: New Approaches to Conflict Resolution. London: I.B. Tauris, pp.24-30.

[4] Anderson, Benedict. 1983.Imagined Communities: Reflections on the Origin and Spread of Nationalism. London: Verso.

[5] Ayubi, Nazih. 1995. Overstating the Arab State. London: I. B. Tauris.

[6] Berkley Center for Religion, Peace \& World Affairs. 2013. 'Lebanon: The Persistence of Sectarian Conflict'. Georgetown University.

[7] Billig, M. 1995. Banal Nationalism. London: SAGE.

[8] Burgess, M. 2007. 'What is to be done? Bicommunalism, federation and confederation in Cyprus'. Michael Burgess and John Pinder (eds.), Multinational Federations. London: Routledge.

[9] Cakal, H. 2012. 'Intergroup relations in northern Cyprus: Turkish Cypriot perspectives'. Department of Psychology. Working Paper No. 2012-1. University of Oxford, Oxford, England.

[10] Calhoun, C. 1997. Nationalism. Buckingham: Open University Press.

[11] Calotychos, Vangelis. 1998. 'Interdisiplinary Perspectives: Difference at the Heart of the Cyprus Identity and Its Study'. Vangelis Calotychos (ed.), Cyprus and Its People. Colarado: Westview Press, pp. 1-32.

[12] Charis Psaltis and HuseyinCakal. 2016. 'Social Identity in a Divided Cyprus'. Shelley McKeown, Reeshma Haji, Neil Ferguson and S. McKeown (eds.), Understanding Peace and Conflict Through Social Identity Theory, Springer International Publishing AG.

[13] Cyprus 2015 poll, available at: http://3n589z370e6o2eata9wahfl4.wpengine.netdna-cdn.com/wpcontent/uploads/2010/03/0000_00_Cyp_interpeace_cyprus2015_poll_presentation_en.pdf 
[14] Dieckhoff, A and N. Gutierrez. 2001. Modern Roots: Studies of National Identity. Contemporary Trends in European Social Sciences series. Aldershot: Ashgate.

[15] Edensor, T. 2002.National Identity, Popular Culture and Everyday Life. Oxford: Berg.

[16] Faustmann, H. 2003. 'Cypriotness in Historical Perspective'. Available at: http://dzforum.de/ downloads/020101001.pdf

[17] Fawaz, E. 2009. 'What Makes Lebanon a Distinctive Country'. Barry Rubin (ed.), Lebanon: Liberation, Conflict and Crisis. New York: Palgrave-Macmillan, pp. .

[18] Hadjipavlou, Maria. 2007. 'The Cyprus Conflict: Root Causes and Implications for Peacebuilding'.Journal of Peace Research, 44(3), p. 357.

[19] Hamit, M. 2009. 'Cypriotism as an Ideology In-between Turkish and Greek Nationalisms'. Master's Thesis. National and Kapodistrian University of Athens.

[20] Harris, W.Lebanese Democracy: Battered, Flawed, and Unmatched in the Arab World, http://www.lebanonrenaissance.org/assets/Uploads/Lebanese-Democracy-Battered-Flawed-And-UnmatchedIn-The-Arab-World-by-William-Harris-2009.pdf

[21] Hitchens,C.1997. Hostage to History: Cyprus from the Ottomans to Kissinger, London: Verso.

[22] Hudson, Michael C. 1997. 'Trying Again: Power-Sharing in Post-Civil War Lebanon'. International Negotiations, No. 2.

[23] Joseph, Joseph S. 1985. Cyprus: Ethnic Conflict and International Politics. London: McMillan Press.

[24] Kaufman, A. 2004. 'Tell Us Our History: Charles Corm, Mount Lebanon and Lebanese Nationalism'. Middle Eastern Studies, 40(3).

[25] Kizilyurek, N. 2005. Dogmamıs, Bir Devletin Tarihi: Birleșik Kıbrıs Cumhuriyeti. 2nd ed. Istanbul: lletişim.

[26] Kizilyurek, N. and S. G. Kizilyurek. 2004. 'The politics of identity in the Turkish Cypriot community and the language question'. International Journal of the Sociology of Language 168.

[27] Lebanon Political Profile. 2006: 'Recent History and Relationship with Syria'.International Debates.

[28] Markides, Kyroacos C. 1977. The Rise and Fall of the Cyprus Republic (New Haven: Yale University Press.

[29] Mavratsas, C. 1996. 'Approaches to Nationalism: Basic Theoretical Considerations in the Study of the GreekCypriot Case and a Historical Overview'. Journal of the Hellenic Diaspora 22(1): 77-102.

[30] Mavratsas, C. 1997. 'The Ideological Contest Between Greek-Cypriot Nationalism and Cypriotism 1974-1995: Politics, Social Memory and Identity'. Ethnic and Racial Studies. 20(4).

[31] Middle East Report. 2012.'A Precarious Balancing Act: Lebanon and the Syrian Conflict', No. 132, 22 November. http://www.crisisgroup.org.

[32] Ożkırımlı, U. 2000. Theories of Nationalism: A Critical Introduction. Hampshire: Palgrave.

[33] Psaltis, C. and E. Lytras. 2012. Unpublished Final Report: Representations of past-present and future: A 3wave longitudinal study across the divide of Cyprus. UNDP-ACT, EU Commission.

[34] Reicher S. and N. Hopkins. 2001. Self and Nation. London: SAGE. 
[35] Riegl, Martin. 2008.'Language and idenity in Cyprus'. The Annual of Language \& Politics and Politics of Identity. 2008, 2(1), 33-45.

[36] Salabi, K. 1976. The Modern History of Lebanon.Greenwood Press.

[37] Salamey, I. and R. Payne. 2008.Journal of Legislative Studies, 14(4): .

[38] Smith, Anthony D. 1991. National Identity. University of Nevada Press.

[39] Stavrinides, Zenon. 1999. The Cyprus Conflict. Lefkosa: CYREP.

[40] Stewart, H. 2012. 'Lebanon's National Identity: Walking Between Raindrops?' The Levantine Review, 1(2).

[41] Taşdemir, Fatma'Suriye İç Savaşı ve Hizbullah Desteği'.Ankara Strateji Enstitüsü, 31 Mayıs 2013.

[42] United Nations Secretary-General. 2004. 'The Comprehensive Settlement of the Cyprus Problem, Fifth Version', http://www.cyprus-unplan.org.

[43] Vural, Y. and A. Rustemli. 2006. 'Identity fluctuations in the Turkish Cypriot community'.Mediterranean Politics 11(3), 329-348.

[44] Yapp, Malcolm 1995. Near East Since the First World War, London: Routledge.

[45] Yilmaz, Muzaffer 2008. 'The Cyprus Conflict and the Question of Identity', SedatLaciner, Mehmet Ozcan, Ihsan Bal and Halil I. Bayar (eds.), Usak Yearbook of International Politics and Law Vol. 1 (International Strategic Research Organisation 2008), pp. 427-446. 